\title{
Effect of Probiotics Addition with Different Dosage on Water Quality Performance of Sangkuriang Catfish (Clarias gariepinus) Farming in the Aquaponic System
}

\author{
Zahidah Hasan ${ }^{1}$, Yuli Andriani ${ }^{2}$, Herman Hamdani ${ }^{3}$, Asep Sahidin and \\ Sukmawati Br. Surbakti ${ }^{4}$ \\ \{ibuzah@gmail.com\} \\ Fisheries Study Program, Faculty of Fisheries and Marine Sciences, \\ Universitas Padjadjaran \\ Jln. Raya Jatinangor Km 21. Sumedang 45363
}

\begin{abstract}
The aim of this study was to determine the appropiate probiotics dose to improve water quality in sangkuriang catfish (Clarias gariepinus) farming on aquaponic system with pakcoy (Brassica rapa L.). This research was conducted from February to March 2018 at Green House Ciparanje Faculty of Fisheries and Marine Sciences Universitas Padjadjaran Jatinangor, while the water quality test was conducted at the Laboratory of Research Centre for Natural Resources and Environment at same university. This research was conducted with an experimental method with a completely randomized design with 4 treatments 3 replications, namely treatment control or without probiotics), probiotics with a concentration of $0.12 \mathrm{ml} / \mathrm{L}$, probiotics with a concentration of $0.25 \mathrm{ml} / \mathrm{L}$, and probiotics with a concentration of $0.37 \mathrm{ml} / \mathrm{L}$. The results showed that treatment addition of probiotic $0.25 \mathrm{mg} / \mathrm{L}$ gave the lowest ammonia and phosphate concentrations, spesific growth rate, survival rate and plant height, that was $0.006 \mathrm{mg} / \mathrm{L}$ and $0.150 \mathrm{mg} / \mathrm{L}, 0,019 \% /$ day, $93 \%$ and $12.20 \mathrm{~cm}$ respectively, meanwhile the lowest nitrate concentration was in treatment without probiotic of 7.094 $\mathrm{mg} / \mathrm{L})$.
\end{abstract}

Keywords: Sangkuriang Catfish, Water quality, Probiotics, Aquaponic.

\section{Introduction}

Catfish (Clarias gariepinus) is one of important freshwater fish and is widely cultivated in Indonesia. Catfish are popular and the price is affordable for all people. catfish production increase over the past five years from to 270,600 tons, in 2010 increase to 900,000 tons in 2014 [1] ( Indonesian Directorate General of Aquaculture 2014). High market demand for catfish need to be fulfilled, by increasing catfish production. One alternative to raise productivity is to develop fish cultivation technology such as aquaponic systems. Aquaponics is concept of bio-integrated farming system, which is a series of technologies that combine aquaculture techniques and hydroponic farming techniques to optimize water and space 
functions as a medium of cultivation [2] (Kurniawan 2013). Aquaculture in aquaponic systems is characterized by the intensive culture in recirculation systems.

Intensive aquaculture has a high stocking density and must provide protein-rich artificial feed [3] (Rudhiyufa 2011). The aquaculture activities will cause water pollution which are originated from uneated feed, feces, urine and others metabolism waste of cultured fish. Fish excrete $80-90 \%$ ammonia through the osmoregulation process while faeces and urine concisted of 10-20\% Ammonia-Nitrogen (TAN) total. TAN which consists of toxic nonionized ammonia (NH3) and ionized ammonia (NH4) [4] (Setijaningsih 2015). Toxic unionized ammonia tends to cause physiological disturbance, and trigger stress on fish [5] (Wijaya et al. 2014). On the other side waste from aquaculture activities believed to have the nutrients that are useful as fertilizer for plants in hydroponic subsystem. While the plants in hydroponic serves as a biofilter that absorb the waste generated from subsystem aquaculture. As intensification level increase unionized ammonia level wiil raised and ammonia intoxication will be worse. To deal with the problem, a new input technology are needed. One of that technology is collaborate aquaponics and Probiotics are beneficial microorganisms for their hosts, namely as controlling disease, completing or replacing the role of antimicrobial compounds, can suppress harmful bacteria, increase the body's immunity so that they can grow well and are not easily stressed as well as bioremediation agents that are useful for improving water quality [6] ( Irianto and Austin 2002). Giving probiotic bacteria to aquaponic systems in catfish maintenance media will oxidize ammonia compounds to nitrites and nitrates. Plants as bological filtration will absorb nitrogen (NH3-N, NO2-N, and NO3-N) and carbon dioxide ( $\mathrm{CO} 2)$ as nutrients so that the quality of catfish culture is maintained. Addition of probiotics in cultivation media is one solution that can be utilized to improve ammonia decomposition and improve water quality [3] (Radhiyufa 2011).

Commercially, probiotics have now been produced mainly in the cultivation of freshwater fish with different bacterial contents. According to Pratama et al [6] (2017) probiotics with Bacilus sp., Lactobacillus sp., Nitrobacter sp., and Nitrosomonas sp. the most optimal for decreasing ammonia levels. Based on this, it is necessary to know information about the appropiate dose of probiotic addition to improve the water quality of catfish rearing media with aquaponic systems.

\section{Materials and Methods}

The research was conducted from February to March 2018 at the Ciparanje Green House, Faculty of Fisheries and Marine Sciences, Padjadjaran University, Jatinangor.

\subsection{Equipment}

The equipment used in this study were $70 \times 70 \times 70 \mathrm{~cm}$ fiber tubs, 12 pieces, 4 and $1 / 2$ inch pvc pipes, iron shelves, water pumps, hoses, plastic cups, DO meters, $\mathrm{pH}$ meters, digital scales, rulers, spectrophotometers.

\subsection{Materials}

The materials used in this study include: 
1. The seed of catfish used are $10 \mathrm{~cm}$ in size with a weight of $11 \mathrm{gr}$ as many as 600 seeds. Each tub contains 50 seeds.

2. The plant used is pakcoy which is sown for 14 days on the media of husk charcoal

3. The probiotics used are consisting of Lactobacillus, Bacillus, Nitrosomonas, Nitrobacter bacteria.

4. Ammonia, phosphate and nitrate test solution (SnCL2, NH4 moblidat, nessler, phenoldissulfonic acid, 10\% NH4OH, aquades).

5. Fish fed with commercial feed (FF 999).

\subsection{Methods}

The method of this research was carried out by the experimental method with a completely randomized design with 4 treatments 3 replications, the treatment consisted of:

A: Control (not given probiotics)

B: probiotic concentration of $0.12 \mathrm{ml} / \mathrm{L}$

$\mathrm{C}$ : concentration of probiotics $0.25 \mathrm{ml} / \mathrm{L}$

D: concentration of probiotics $0.37 \mathrm{ml} / \mathrm{L}$

\subsection{Research Procedure}

The research was carried out through several procedures,:

1. Rearing container preparation which includes cleaning, sterilization, drying, and water filling

2. arrangement of an aquaponic installation begins with the installation of a PVC pipe, placing a fiber container, then installing a water pump, and finally filling the water in the fiber container.

3. Fish acclimatization and fish seeds are stocked with a density of 50 fish $/ 245 \mathrm{~L}$ container.

4. Pakcoy nursery is carried out on the husk charcoal media using a tray, then stored in the shade area. Watering is done in the morning and evening. After the plant seeds are 14 days old, its transferred to a plastic cup and then placed in an aquaponic installation.

5. Fish are fed twice a day using FF999 commercial feed. Feeding is done in the morning at 09.00 and in the afternoon at 15.00. Feeding is done by satiation procedure.

6. probiotics added in every ten days.

7. Water quality parameters of ammonia, nitrate and phosphatetested in every ten days, meanwhile the other parameters ( $\mathrm{DO}$, temperature and $\mathrm{pH}$ ) measured 2 times daily, in the morning of 06.00 and in the afternoon at 17.00 .

\subsection{Observed Parameters:}

1. Water quality: temperature, $\mathrm{pH}, \mathrm{DO}$, nitrate, phosphate, ammonia.

2. Plant growth:

Average plant height $=\mathrm{Y} 1-\mathrm{Y} 0 / \mathrm{N}$

Average numbers of leaf $=\mathrm{Z} 1-\mathrm{Z} 0 / \mathrm{N}$ 
Information :

Y1: Plant height at the end of the study

Y0: Plant height at the beginning of the study

Z1: Number of leaves at the end of the study

Z0: Number of leaves at the beginning of the study

$\mathrm{N}$ : time of study (days)

3. Survival rate of catfish

The survival of catfish is observed every day and analyzed using the Effendi formula [7] (1997) as follows:

Information :

$$
\mathrm{SR}=\frac{N t}{N o} \times 100 \%
$$

$\mathrm{SR}=$ Degree of survival (\%)

$\mathrm{Nt}=$ Number of live fish at the end of the study

No $=$ Number of seeds at the beginning of the study

4. Fish Growth

To calculate the daily growth rate of fish, the formula [7] is used as follows:

$$
\mathrm{G}=\frac{\ln W t-\ln W o}{T} \mathrm{x} 100 \%
$$

noted

$\mathrm{G}=$ Growth rate $(\%)$

Wo $=$ initial weight $(\mathrm{gr})$

$\mathrm{Wt}=$ final weight $(\mathrm{gr})$

$\mathrm{T}=$ time of study (days)

\subsection{Data Analysis}

Data on water quality (temperature, $\mathrm{pH}, \mathrm{DO}$, nitrate, phosphate, ammonia), length growth and increase in leaf of pakcoy plants were analyzed descriptively and presented in the form of tables and graphs using a range value then compared with existing literature and nasional water quality standard 9][ (PP no 82/2001).

The effect of the treatment given on the growth of fish weight and the survival of catfish was analyzed using variance (ANNOVA) with the F test at the 95\% confidence level. If there are significant differences between treatments, then the test is followed by Duncan's multiple range test with a confidence level of $95 \%$.

\section{Result and Disscussion}

\subsection{Temperature, pH, DO (Dissolved Oxigen)}

Based on the results of water temperature during the study ranged from $24.1^{\circ} \mathrm{C}-25.1^{\circ} \mathrm{C}$. According to BBPBAT [8] (2005), the ideal temperature range for catfish growth ranges from 
$22^{\circ} \mathrm{C}-32^{\circ} \mathrm{C}$. Based on it, temperature range is still in a normal condition. According to Effendi (2003) the temperature in fish culture media will affect the growth rate, metabolic rate and fish appetite due to the increased performance of digestive enzymes.

Acidity $(\mathrm{pH})$ value during the study showed a range between 6.0 - 7.8. That value range still in optimal range for catfish which ranges between 6-9 (Khairuman and Amri 2003). Acidity value above 9.2 or less than 4.8 can result in decreased reproductive capacity, fish growth can even lead to death in fish. The decrease in $\mathrm{pH}$ at all treatment is related to released of carbon dioxide $\left(\mathrm{CO}_{2}\right)$ as respiration product of organisms include fish and bacteria.

Dissolved oxygen concentration ranged from 5.7-7.1 $\mathrm{mg} / \mathrm{L}$. this range still in normal conditions for sangkuriang catfish. Optimum dissolved oxygen catfish maintenance ishigher than $4 \mathrm{mg} / \mathrm{L}$ with a minimum value limit of $3 \mathrm{mg} / \mathrm{L}$ [9] (PP No. 82 of 2001). In condition with Oxygen concentration less than $4 \mathrm{mg} / \mathrm{L}$, catfish can still survive because it has an additional respiratory device to uptake oxygen from the air, but its appetite will begin to decline, which results in slow growth of fish, while dissolved oxygen less than $1 \mathrm{mg} / \mathrm{L}$ can be toxic for most fish species (Kordi 2009). Below (Figure 1) is a graph of temperature, pH, DO obtained during the study.

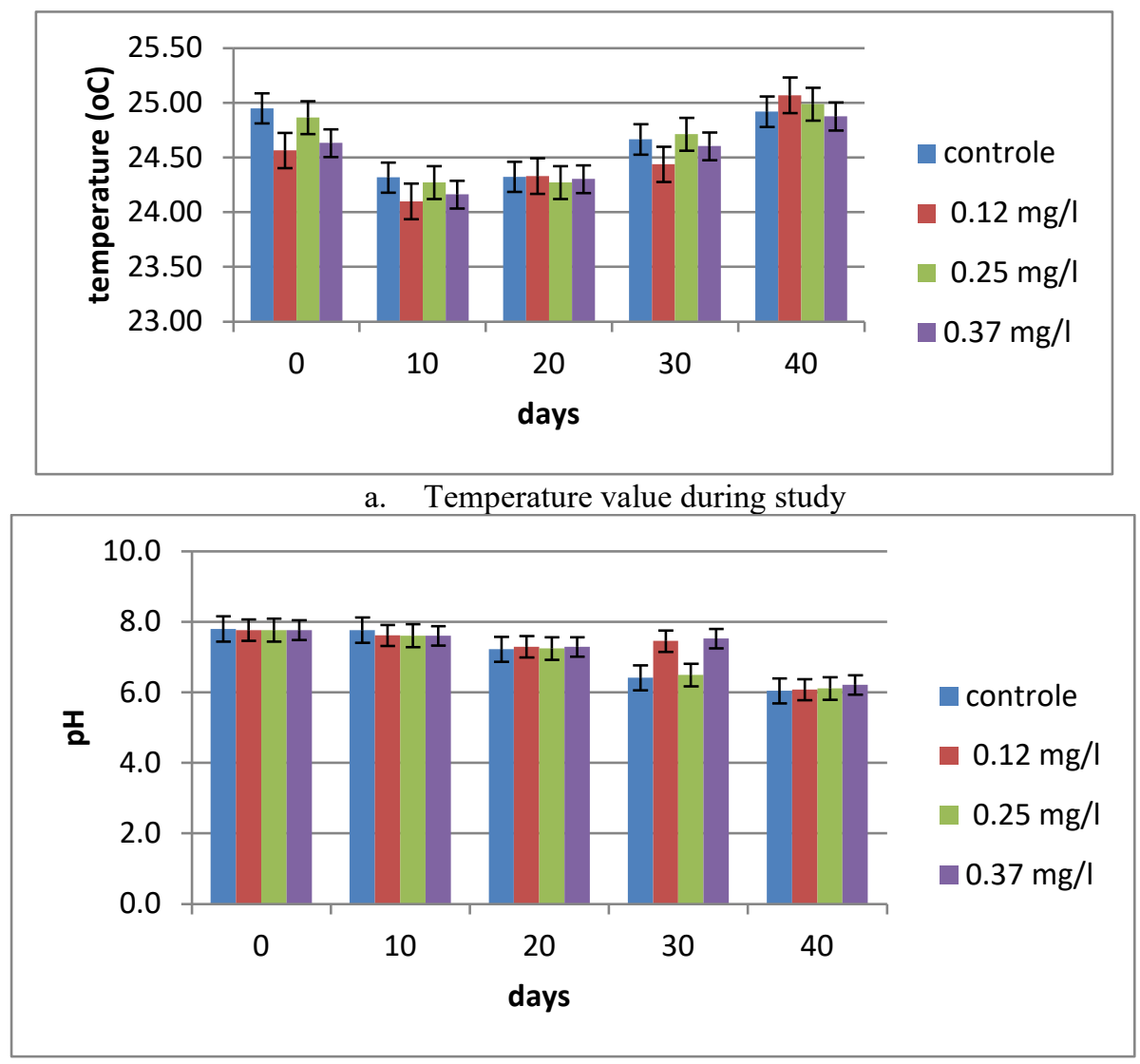

b. pH value during study 


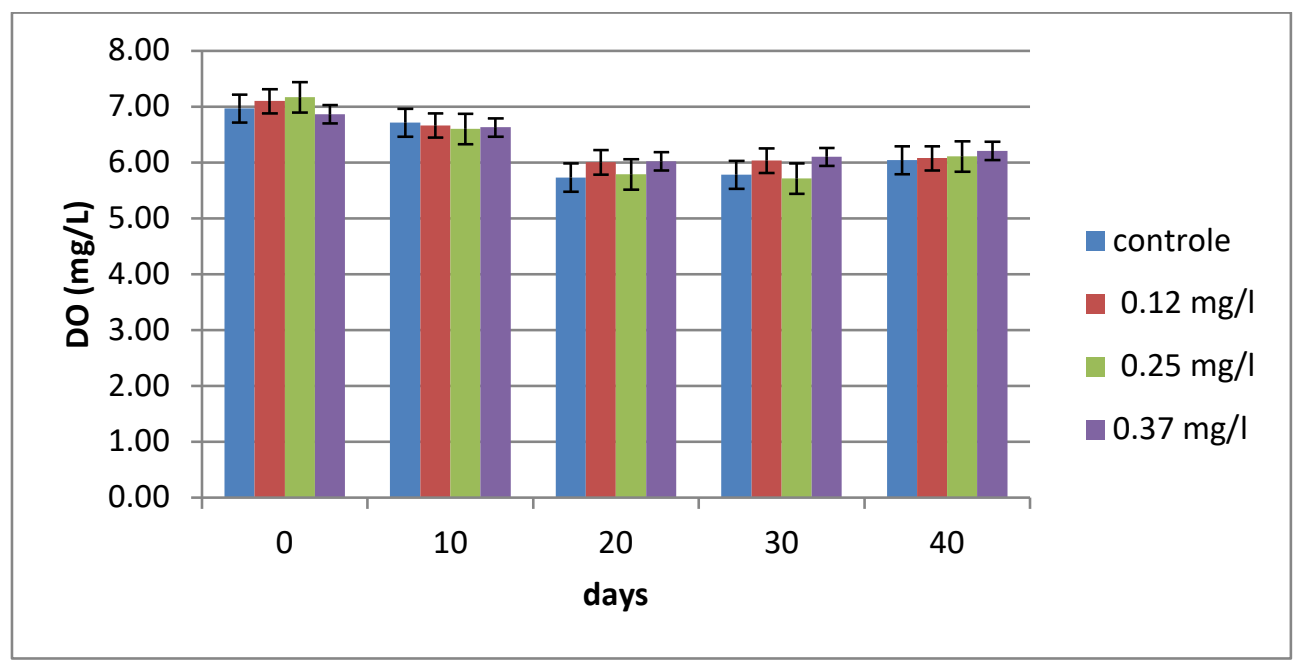

c. Dissolved Oxygen concentration during study

Figure 1. Temperature, $\mathrm{pH}$ and DO during study

\subsection{Ammonia (NH3) concentration}

Ammonia concentrations during study ranged from $0.003 \mathrm{mg} / \mathrm{L}-0.056 \mathrm{mg} / \mathrm{L}$. Ammonia concentration fluctuates and is still at the safe limit for catfish rearing, this is similar with the statement of BBPBAT [10] (2005) that the ammonia concentration in the catfish rearing must be less than $0.8 \mathrm{mg} / \mathrm{L}$. According to Effendi et al (2015) the water temperature will affect the performance of enzymes in bacteria, that is, the higher the water temperature, the bacterial metabolic process will increase so that the nitrogen decomposition activity will be faster.

Nitrification will run well on dissolved oxygen more than $1 \mathrm{mg} / \mathrm{L}$, temperature $25-35^{\circ} \mathrm{C}$ and $\mathrm{pH} 7.5-8.6$ because in that range nitrifying bacteria can grow well (Crab et al. 2007). At the first 10 days of dissolved oxygen ranged from $6.6-6.7 \mathrm{mg} / \mathrm{L}, \mathrm{pH} 7.6-7.8$ and temperature 24.1-24.3 oC, so that at that period the nitrification process did not go on well, due to the relatively lower temperature and bacteria still in adaptation stadia. This condition raised ammonia concentration. Fluctuations in ammonia concentration during the study can be seen in Figure 2. 


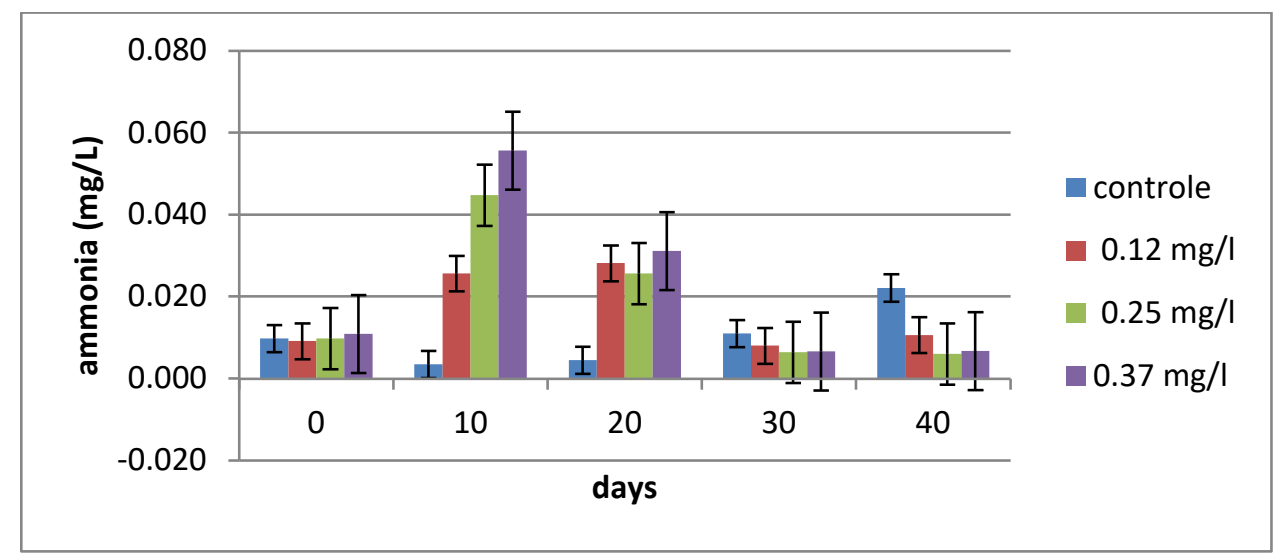

Figure 2. Ammonia concentration during study

\subsection{Nitrate concentration (NO3)}

During study, the concentration of nitrate fluctuated, showing a range between $0.10 \mathrm{mg} /$ $\mathrm{L}-11.56 \mathrm{mg} / \mathrm{L}$. This condition is still within tolerance for catfish growth, and also below the maximum value of water quality standard, which is less than $20 \mathrm{mg} / \mathrm{L}$ [9] (PP No. 82 of 2001). The higher the dose of probiotics given, the higher the concentration of nitrate. Increased nitrate concentration is related to nitrifying bacteria go well converting ammonia to nitrate. The addition of probiotics to catfish rearing container, the nitrification process can run optimally so as to produce high enough nitrate. Fluctuations in nitrate concentration during the study can be seen in Figure 3.

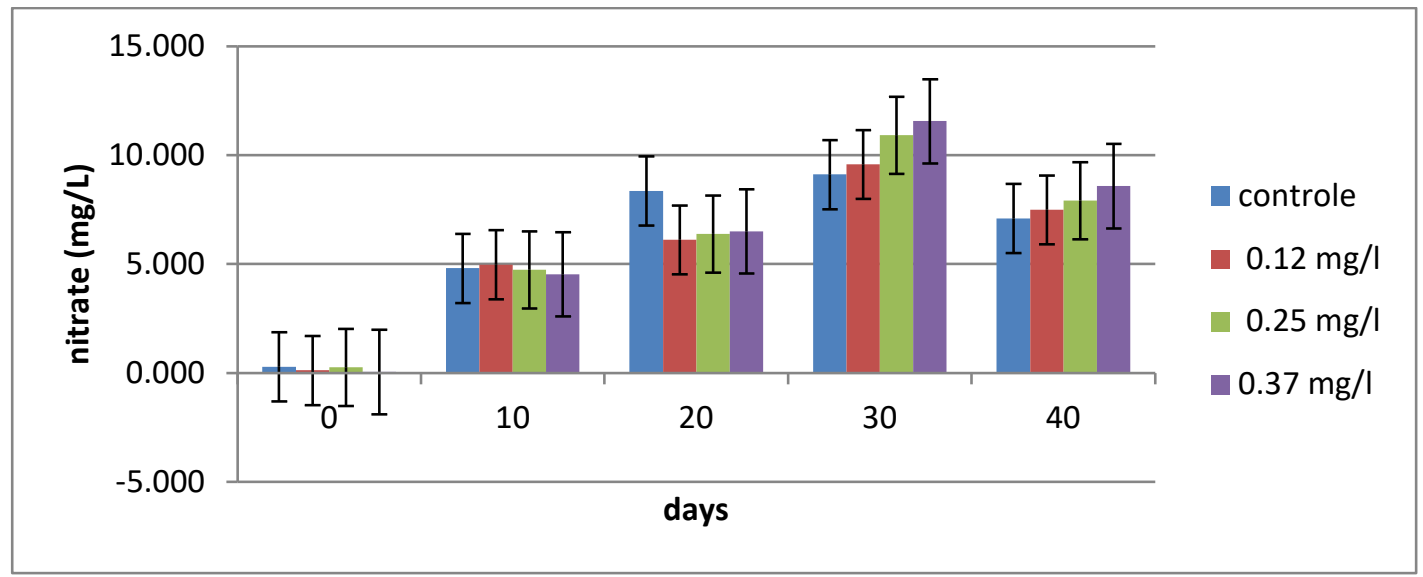

Figure 3. Nitrate concentration during study

\subsection{Phosphate Concentration}

Based on the results, phosphate concentration during the study fluctuated which ranged from $0.09 \mathrm{mg} / \mathrm{L}-0.23 \mathrm{mg} / \mathrm{L}$. Phosphate concentration still in optimum range, and below the 
maximum water quality standard, which is less than $1 \mathrm{mg} / \mathrm{L}$ [9] (PP No. 82 of 2001). The increase in phosphate related to a accumulation of the fish's metabolism and also the uneaten feed. According to Hendrawati et al. (2007) high phosphate concentrations derived from excretion of fish in the form of feces. Fluctuations in phosphate concentration during study can be seen in Figure 4.

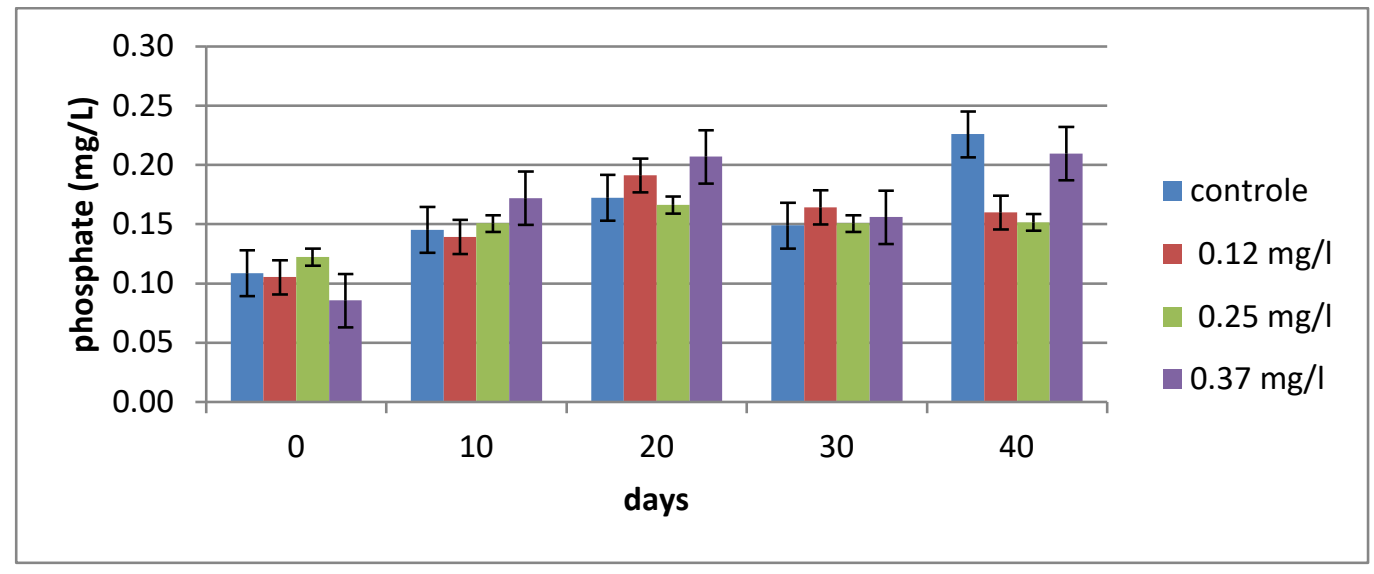

Figure 4. Phosphate concentration during study

\subsection{Specific Growth of Catfish}

Specific growth rates or Specific Growth Rate (SGR) of catfish ranged from $0.15-0.019 \%$ / day and showed a significant effect $(p<0.05)$ of probiotics on the specific growth rate of catfish. The results of the calculation of Analysis of Variants (ANOVA) showed significant differences $(\mathrm{p}<0.05)$ between treatments $\mathrm{C}$ with $\mathrm{A}, \mathrm{B}$, and $\mathrm{D}$, but treatments $\mathrm{A}, \mathrm{B}$ and $\mathrm{D}$ were not significantly different. It is known that the highest specific growth rate is found in treatment $\mathrm{C}$ which is $0.019 \%$ / day, while the lowest specific rate in treatment $\mathrm{A}$ and $\mathrm{B}$ is $0.015 \%$ / day. The average data on specific growth rates of catfish can be seen in Table 1 .

Table 1. Catfish Specific Growth

\begin{tabular}{ll}
\hline Treatment & SGR $(\% /$ day $)$ \\
\hline A (without & $0.015^{\mathrm{a}} \pm 0,0009$ \\
probiotic) & \\
$\mathrm{B}(0.12 \mathrm{mg} / \mathrm{L})$ & $0.015^{\mathrm{a}} \pm 0,0006$ \\
$\mathrm{C}(0.25 \mathrm{mg} / \mathrm{L})$ & $0.019^{\mathrm{b}} \pm 0,0008$ \\
$\mathrm{D}(0.37 \mathrm{mg} / \mathrm{L})$ & $0.016^{\mathrm{a}} \pm 0.0014$ \\
\hline
\end{tabular}

noted: Different superscripts in the same column show significant differences $(\mathrm{p}<0.05)$

The high specific growth rate shows the probiotic concentration of $0.25 \mathrm{ml} / \mathrm{L}$ are able to work optimally both in improving the quality of water and also working in the digestive tract of fish. According to Ernawati et al. (2014) the utilization of Bacillus bacteria has a positive effect on growth, the enzymes produced by bacteria are consumed and helped the digestive process, then bacteria produce protease and lipase enzymes which function to accelerate protein hydrolysis reactions and cut peptide bonds to produce growth well. According to 
Martoharsono et al. (2006), Lactobacillus bacteria are lactic acid bacteria that can decompose carbohydrates into lactic acid. The lactic acid produced can inhibit the growth of pathogenic microorganisms.

The growth rate in treatment $\mathrm{A}$ is having the lowest growth relative to other treatments. This is related to the lack of bacterial content in treatment A. Treatment B with a probiotic dose of $0.12 \mathrm{ml} / \mathrm{L}$ is not enough bacteria content to improve the digestion of catfish. Growth in treatment $\mathrm{D}$ was lower compared to treatment $\mathrm{C}$ was thought to be due to more bacterial doses of $0.037 \mathrm{ml} / \mathrm{L}$. According to Aquarista et al. (2012) the high bacterial content resulted in competition between bacteria in the use of nutrients which inhibited the performance of bacteria.

\subsection{Survival Rate of Catfish}

The results showed that the SR or catfish survival rate ranged from 74.67 to $93 \%$. The highest level of liveliness of catfish is obtained in treatment $\mathrm{C}$ of $93 \%$, while the lowest catfish life is found in treatment $\mathrm{D}$ of $74.67 \%$. The results of the calculation of Analysis of Variants (ANOVA) showed no significant differences $(p<0.05)$ between treatments for catfish survival. Survival Rate data of catfish during observations can be seen in Table 2 .

Table 2. Survival rate $(\%)$

\begin{tabular}{ll}
\hline treatment & $\begin{array}{l}\text { Survival Rate } \\
(\%)\end{array}$ \\
\hline A (without probiotic) & $86,00^{\mathrm{a}} \pm 12,17$ \\
B $(0.12 \mathrm{mg} / \mathrm{L})$ & $89,00^{\mathrm{a}} \pm 12,06$ \\
$\mathrm{C}(0.25 \mathrm{mg} / \mathrm{L})$ & $93,00^{\mathrm{a}} \pm 6,11$ \\
$\mathrm{D}(0.37 \mathrm{mg} / \mathrm{L})$ & $74,67^{\mathrm{a}} \pm 4,16$ \\
\hline
\end{tabular}

noted: Different superscripts in the same column show significant differences $(p<0.05)$

The high survival rate in treatment $\mathrm{C}$ shows that the administration of probiotics with a dose of $0.25 \mathrm{ml} / \mathrm{L}$ is optimal in supporting the survival of catfish. Pitrianingsih (2014) states that giving probiotics with optimal concentration can provide ideal ecosystem conditions and can increase the number of catfish lives. The low SR value of catfish in treatment $\mathrm{D}$, due to fish deaths due to a drastic increase in ammonia levels on the 20th day. Day 0 of ammonia concentration was $0.001 \mathrm{mg} / \mathrm{L}$, but on day 20 ammonia increased to $0.056 \mathrm{mg} / \mathrm{L}$. Water quality is one of the main factors in maintaining fish survival. According to [22] (Khairuman 2005) water quality that is good for fish maintenance will provide better fish life.

\subsection{Productivity of Pakcoy Plants}

Addition of plant length to the number of pakcoy leaves during the observation can be seen in Table 3. 
Table 3. plant productivity

\begin{tabular}{|c|c|c|c|c|}
\hline \multirow[b]{2}{*}{ Parameters } & \multicolumn{4}{|c|}{ treatment } \\
\hline & $\begin{array}{l}\text { A } \\
\text { without } \\
\text { probioti } \\
\text { c }\end{array}$ & $\begin{array}{l}\mathrm{B} \\
(0.12 \\
\mathrm{mg} / \mathrm{L})\end{array}$ & $\begin{array}{l}\mathrm{C} \\
(0.25 \\
\mathrm{mg} / \mathrm{L})\end{array}$ & $\begin{array}{l}\mathrm{D} \\
(0.37 \\
\mathrm{mg} / \mathrm{L})\end{array}$ \\
\hline $\begin{array}{l}\text { Plant height } \\
(\mathrm{cm})\end{array}$ & 10,40 & 10,68 & 12,20 & 11,25 \\
\hline $\begin{array}{l}\text { Numbers of } \\
\text { leves }\end{array}$ & 7 & 7 & 8 & 9 \\
\hline
\end{tabular}

The lowest growth in length is found in treatment A (control) which is $10.40 \mathrm{~cm}$, this is because there are aphids on pakcoy plants in treatment A which interfere with the absorption of nutrients (nitrate and phosphate) in plant rearing media. The highest growth length is found in treatment $\mathrm{C}$, which is $12.20 \mathrm{~cm}$. This is due to the optimal absorption of nitrate in treatment $\mathrm{C}$ from the decomposition of ammonia by a biological filter added by probiotic bacteria. Nitrate is a form of nitrogen that is in natural waters and is also a nutrient for plant growth (Hendriyana 2014).

\section{CONCLUSIONS}

Based on the results, the following conclusions can be drawn:

1. Addition of probiotics with different doses in aquaponic systems has an effect on improving water quality, especially decreased the concentration of ammonia and phosphate. The lowest ammonia concentration at the end of the study was found in treatment probiotics with a dose of $0.250 \mathrm{~mL} / \mathrm{L}$ of $0.006 \mathrm{mg} / \mathrm{L}$ and phosphate concentration of $0.150 \mathrm{mg} / \mathrm{L}$. The lowest nitrate concentration at the end of the study was in treatment without probiotic addition of $7.094 \mathrm{mg} / \mathrm{L}$.

2. Addition of different probiotic doses on aquaponic systems has a significant effect ( $\mathrm{p}$ value $=0.05$ ) on the growth rate and catfish survival rate (Clarias gariepinus). The highest survival rate and growth rate is found in treatment probiotics with a dose of $0.25 \mathrm{ml} / \mathrm{L}$ with an SR value of $93 \%$ and a specific growth rate of catfish which is $0.019 \%$ / day.

3 . The highest growth of pakcoy plants is found in treatment probiotics with a dose of $0.25 \mathrm{ml}$ / $\mathrm{L}$ which is $17.9 \mathrm{~cm}$, and the highest number of leaflets is found in treatment probiotics with a dose of $0.37 \mathrm{ml} / \mathrm{L}$ that is as many as 13 strands.

\section{References}

[1] "KKP | Kementerian Kelautan dan Perikanan." [Online]. Available: https://kkp.go.id/artikel/945-direktorat-jenderal-perikanan-budidaya. [Accessed: 16Jan-2020].

[2] "andri Kurniawan - Pengutipan Google Scholar." [Online]. Available: https://scholar.google.co.id/citations?user=Ztobt1QAAAAJ\&hl=id. [Accessed: 16Jan-2020].

[3] "Dinamika fosfat dan klorofil dengan penebaran ikan nila ( oreochromis nilotocus) 
padas kolam budidaya ikan lele (clarias gariepinus) sistem heterotrofik - 123dok." [Online]. Available: https://text-id.123dok.com/document/dzxn9rdq-dinamika-fosfatdan-klorofil-dengan-penebaran-ikan-nila-oreochromis-nilotocus-padas-kolam-

budidaya-ikan-lele-clarias-gariepinus-sistem-heterotrofik.html. [Accessed: 16-Jan2020].

[4] A. Santoso, "PERKEMBANGAN TEKNOLOGI SEL MAMALIA CHINESE HAMSTER OVARY (CHO) UNTUK PRODUKSI OBAT BERBASIS PROTEIN," Ber. Biol., vol. 18, no. 2, pp. 125-133, Aug. 2019, doi: 10.14203/beritabiologi.v18i2.3705.

[5] O. W. B. S. R. Prayogo, "Pengaruh Padat Tebar Ikan Lele Terhadap Laju Pertumbuhan Dan Survival Rate Pada Sistem Akuaponik $<\mathrm{Br}><\mathrm{I}>[$ The Effect Of Stocking Density On Survival Rate And Grow Rate Of Aquaponic System $]<\mathrm{I}>$," $J$. Ilm. Perikan. dan Kelaut., vol. 6, no. 1, p. 55, Jan. 2019, doi: 10.20473/jipk.v6i1.11382.

[6] A. Irianto, H. Hernayanti, and N. Iriyanti, "Pengaruh Suplementasi Probiotik A3-51 terhadap Derajat Imunitas Oreochromis niloticus Didasarkan pada Angka Kuman pada Ginjal Setelah Uji Tantang dengan Aeromonas hydrophila dan Aeromonas salmonicida achromogenes," J. Perikan. Univ. Gadjah Mada, vol. 8, no. 2, p. 144, Jul. 2006, doi: 10.22146/jfs. 126 .

[7] "DAFTAR PUSTAKA."

[8] "TELAAH KUALITAS AIR, Bagi Pengelolaan Sumber Daya dan Lingkungan Perairan - Hefni Effendi - Google Buku." [Online]. Available: https://books.google.co.id/books?id=HyjDhfW87B0C\&printsec=copyright\&hl=id\#v= onepage \&q\&f=false. [Accessed: 16-Jan-2020].

[9] "Peraturan Pemerintah No. 82 Tahun 2001 tentang Pengelolaan Kualitas A...." [Online]. Available: https://www.slideshare.net/infosanitasi/pp-82-th-2001pengelolaan-kualitas-air-dan-pengendalian-pencemaran-air. [Accessed: 16-Jan-2020].

[10] "Teknik Pembenihan Ikan Lele Sangkuriang (Clarias sp) di BBPBAT KKP Sukabumi Jawa Barat | Syahroni, S.Pi.” [Online]. Available: https://syahroniwongcirebon.wordpress.com/2018/03/23/teknik-pembenihan-ikan-lelesangkuriang-clarias-sp-di-bbpbat-kkp-sukabumi-jawa-barat/. [Accessed: 16-Jan2020]. 